\title{
Youth Empowerment in Higher Education for Sustainable Development of Developing Communities in Cross River State, Nigeria
}

\author{
WILLIAM E. EKPIKEN ${ }^{1} \&$ GODFREY U. UKPABIO ${ }^{1}$ \\ ${ }^{1}$ Department of Educational Administration and Planning, University of Calabar, Calabar, Nigeria \\ Correspondence: WILLIAM E. EKPIKEN, Department of Educational Administration and Planning, University \\ of Calabar, Calabar, Nigeria. Tel: 80-3344-7518. E-mail: williamekpiken@yahoo.com
}

Received: December 12, 2014 Accepted: April 23, 2015 Online Published: August 27, 2015

doi:10.5539/ies.v8n9p113

URL: http://dx.doi.org/10.5539/ies.v8n9p113

\begin{abstract}
This paper was an attempt to examine youth empowerment in higher education for sustainable development of developing communities in Cross River State in Nigeria. In Cross River State developing communities, youths are in the majority and form a very strong formidable force in the society we live, study, but are not empowered while in school nor after graduation. Hence, they rarely contribute to sustainable development of their communities. To address this problem, three research questions and three hypotheses were formulated to guide the study. The design of the study was ex-post facto. The sample of the study was one hundred and forty six (146) youths drawn out of a population of five hundred (500) youths in the study area. The instrument used for data collection and analysis was a self-developed research questionnaire comprising 30 items. The data was analyzed using Pearson product moment correlation analysis. The result of the analysis showed that when youths in higher educational institutions are empowered, they will contribute to sustainable development of their communities. Based on the conclusion, the paper recommended that government, parents and stakeholders should address the issue of youth empowerment in educational institutions to enable them acquire skills for empowerment in the society.
\end{abstract}

Keywords: youth empowerment, higher education, sustainable development

\section{Introduction}

The concept of education at all levels has been seen as a major factor in national development and a key to empowerment of people towards nation building. This is particularly the case in today's globalized information and knowledge based economy. No country can expect to successfully integrate in and benefit from the 21 st century economy without a well-educated and empowered workforce, who in this context is the youths, Ojedele and Falokin (2009). The need therefore for a more purposeful and functional higher education for youth cannot, be overemphasized because, sound higher education is the best empowering tool for youth in sustainable development of the society.

Taking a cursory look at the history of higher education it is obvious that the youths in the state have not been given full opportunity to benefit from higher education. The implications of these challenges are that the youth's inability to have access to appropriate higher education is due to ignorance, poverty and disease. The stakes of these forces are particularly high for developing communities, given the low level of education attainment generally of the communities' labour force. The yearnings of the people more importantly the youths for higher level of education must be satisfied. This, according to Okeke and Emenalo, has become imperative because Nigeria's future prosperity particularly at the community levels depends on the production or empowerment of youths who are well prepared and equipped to play their roles in tomorrow's global society; as well as appreciating the indispensability of peace and security that are ingredient for progress and sustainable development.

On the contrary, Okpeh (2005) stated vehemently that, if youths are not empowered and given responsibilities in the society, they are likely to constitute a threat to national survival and stability, especially, if they are allowed to drift, unemployed ill-disciplined and morally bankrupt. From this analysis therefore, it is very pertinent to empower the youths through such measures and strategies like entrepreneurship training, skills acquisition, 
access to credit facilities and qualitative education with unlimited life-enhancing opportunities. This would ultimately transform our youths from a polite economic entity to the level of high productivity and sustainable development.

\subsection{Youth Participation and Empowerment}

Entrepreneurship education contributes to nation building through its ability to provide training that will result in developing individuals who are well adjusted in the sense that they are capable of coping with their communities and the world in which they live and providing the understanding and appreciation of the actual functioning of the economic system due to its competency-based in nature. Entrepreneurship education as a course has been introduced into Nigerian higher institution particularly in Business education programme.

Business education is education for and about business or training in business skills. In business education, wide range of courses are offered such as marketing, accounting, information and communication technology, business policy, management, business law and entrepreneurship to mention a few. Business education graduates are expected to acquire business competencies from these courses. These competencies will enable them to set up their own business and manage them effectively.

Youth empowerment through higher education according to Okeke and Emenalo (2008) can be realized through teaching, research, creation, dissemination and services to the community. They further maintained that this can also be possible if properly and effectively pursued and complete actualization youth empowerment is always assured. To this end therefore, educational experiences of youths have to be such that it is conducive to promoting not only the fullest individual development but also the acquisition of knowledge, attitudes, behaviours and occupational skills that are appropriate for maintaining the social status quo, advancing economic progress and developing individual (youth) personality (Okpete, 2005).

In Cross River State developing communities, the youths are in the majority and form a formidable force. Although, this is a period of exhibition of their innate quality and show-case their God-given talent, but, it is regrettable that most times, youths live, study and work under precarious conditions, sometimes they are dehumanized and underrated and their freedom abused leading to insecurity, marginalization and neglect. Youth empowerment in higher education is indispensable because at this level, they are exposed to useful program as that will equip them with the necessary skills for life-long living in the community. These skills if properly taught by the teachers and learnt by the students will help greatly for the nation economic growth and sustainable development and to their communities.

Okpan (2006) and Ekue and Udoye (2008) identify some accounting skills which are required by business education graduates for successful entrepreneurship. These are ability to keep and control stocks, ability to avoid unplanned expenditure, ability to determine profit at a particular period, ability to find sources of capital to start business, ability to understand recording of business transaction.

Okpan (2006), Okoro and Amagoh (2008) identify the following office education skills, ability to understand the different filing systems, ability to manage information effectively, ability to demonstrate knowledge of computer system, ability to use the different of computer system, ability to follow trend in information technology, ability to write mailable letters and so on. Other management skills include, ability to plan, organize and manage small scale business, ability to develop skills for effective supervision and co-ordination, ability to apply integrating business skills, ability to maintain lousiness, ethics and ability to interpret market information, also to identify marketing skills, such as ability to capture and retain the attention of customers, ability to promote and sell the organization's product analyze demand and supply situations and to acquire effective sales habits.

Youths are the cornerstone of any meaningful and sustainable development. Therefore there is the need to provide a more functional and effective education in the country. Youths constitute about 60 percent of the nation's population and are styled leaders of tomorrow. They represent the most vibrant and productive of all the segments of the society.

Therefore, neglecting them mean to draw back the hands of the clock of the nation's socio-economic and political development. Nigerian Breweries has inaugurated Maltina Teacher of the Year Award on the platform of the Felix Ohiwerei Education Trust Fund in honour of Mr. Ohiewerei, the first indigenous Chairman of the Company. The Trust Fund is N 50 million for teachers who transcend professional and personal challenges to make a difference in their institution. This initiative is also to recognize and celebrate exceptional teachers in the country and to accord them their deserved credit and bring back respect to the profession in Nigeria. This award is annually and the Human Resources Director of the company said that teachers are the builders of the wealth of nation and deserved to be celebrated. 
Everywhere in the world, teachers play a vital role in training, coaching and determining the quality of education and this is critical to sustainable national development. This initiative will provide vital information to enable them to seek suitable careers, interest and skills. This Trust Fund since its inception has supported various educational projects across 40 communities, such as building of 250 classrooms and 22 libraries in secondary and higher institution and donation of laboratory equipment and other materials to tertiary institutions including skills acquisition centres in higher institutions.

Also, the founder, Wilson Badeso Foundation has stressed the need for the in-coming government to enact more policies that will promote entrepreneurial education in the country. The foundation emphasized on the need to focus more on youth development. Mr. Badejo said that to make students and youths self-reliant is to formulate policies especially in the education sector, to promote entrepreneurship through appropriate curricular innovative programmes. The foundation since its inception has offered 180 scholarships. These borders on the foundation's objectives which is on education and poverty alleviation. This is also continuous annually. A non-governmental organization Rubies Ink has a programme titled "YES" young empowered and succeeding. The aim of this programme is to directly influence the lives of teenagers by being part of their growth process and activities through out-of-class educative programmes. The programme also make role of celebrities and youth advocates more useful in their everyday contribution to their communities by sustaining them as behavioural and attitudinal change agents of the society. The strategy of the programme is offering young people of secondary and higher institutions the opportunity to discover the right path to self-discovery through programmes and life coaching sessions. These youth advocates are the vehicle of social change that motivate and inspire young Nigerians as role models in their various communities through these entrepreneurship programmes for sustainable development.

\section{Literature Review}

The issue of youth empowerment through schooling or acquiring functional literacy should involve skills acquisition for self-reliance and self-actualization. It is only by acquiring such entrepreneurship position that they can contribute meaningfully to sustainable development of their communities and the nation. This type of education according Stammers and Patrick (2006) involves activities which are aimed at developing youth moral values and understanding required in all works of life, rather than knowledge and skills relating to only a limited field of activity. In conclusion, they affirmed that the purposes of higher education for youths is to provide the conditions essential for young persons and even adult to develop an understanding of the traditions and ideas influencing the society in which they live of their own, and to acquire linguistic and other skills, which are basics to learning personal development, creativity and personal development.

In a research study carried out by Etuk, Etudor-Eyo, and Ekpo (2009) on widening employment opportunities for African youth through higher education, they suggested measures to be taken by higher education leaders towards the empowerment of youths for development. As government addresses the problem of youths, higher educational institutions are urged to contribute meaningfully in empowering/establishing the youths and to add value to their products respectively. To this end, higher education has been urged to institute reforms in their academic programmes that would benefit the youths and meet their needs. Such reforms of academic programme, they added, should focus on rationalization of higher education programmes and emphasizing on the acquisition development of skills among others.

One of the challenges facing university and higher education today in the production of graduates of internationally accepted standard with appropriate knowledge and skills in their various disciplines making such graduates not only highly employable by self but be able to employ others as entrepreneurship education seeks to find how best graduates can convert their education to intellectually productive ventures. Sustainable development is meeting the needs of the present without compromising the ability of the future generation to meet their own needs. Thus sustainable development is doing anything useful for creating wealth and improving the life of men without diminishing them.

The role of entrepreneurship in economic, political, and social development involves more than just increasing per capita income and output, it, also involves imitating and constituting change in the structure of business and society, which is accomplished by growth and increased output, leading to sustainable development of self, the immediate society, the nation and the world at large. It is through this that, youth participation in higher education programmes can contribute to sustainable development in communities, and the nation at large.

Generally, the impact of youth empowerment has been growing rapidly and currently forms about $60 \%$ of the total population of our communities. Effective youth empowerment eliminate unemployment, inaccessibility to information, low education level, vulnerability to HIV and AIDS, non-involvement in governance and human 
right issues, resulting in development and peace building in our countries, while security is assured. If the youths are excluded from participating in the country's development as well as peace building process, by depriving them of these survival conditions they become vulnerable to violence, since they are polarized and marginalized (Okeke \& Emenalo, 2010). This developmental scenario is clearly evident in the recent socio-political violence in some parts of Nigeria.

In addition, since youth is a key stage in the life of every human being, every society or community look up to the youths for qualities of leadership, knowledge, integrity and enthusiasm - youths of today are leaders of tomorrow and as such need to acquire sound education to enable them contribute to the direction of development. It is pertinent for future leaders of our nation to be aware that the state current predicament and challenges of the $21^{\text {st }}$ century is due to poor empowerment of youth through unorganized higher education programmes for youth\$ who are not properly equipped for the world of works (Dike, 2007), this vision should be sustained for development purpose.

The genesis of youth empowerment is going through a period of uncertainty due to the rise in unemployment particularly among youths in Cross River State developing communities. Youth unemployment and lack of decent life opportunity is a pressing problem currently affecting sustainable development of our communities. However, the recent clamour for youth employment in all its ramifications has somehow improved youths. The youths need to gain appropriate skills, independence and freedom of choice about their lives.

Dishearteningly however, the observation is that opportunities through higher education as a tool to empower youths with equal opportunities, entrepreneurship skills and employment creation which should be available to millions of youths are very limited. This situation has forced the youths to remain dependent, unemployed and vulnerable for a long period of time now. Empowering them has a higher prospect for them towards increasing their potentials to building a virile community and producing better future leaders and a better society.

\section{Research Questions}

In addressing above problems, the following research questions were raised.

- Does entrepreneurship programme for youth empowerment in higher education influence sustainable development of communities.

- Does youth participation in higher education programme influence their contributions sustainable development

- Does youth acquisition of skills in higher education influence sustainable development.

\section{Research Hypotheses}

To guide the analysis of the study the following hypotheses were formulated.

- Entrepreneurship programme for youth empowerment does not significantly influence sustainable development.

- Youth participation in higher education programme does not significantly influence sustainable development of communities

- Youth acquisition of skills from higher education does not significantly influence sustainable development.

\section{Methodology}

The study took the quantitative empirical approach or paradigm in that it was based on the variables measured with numbers and analyzed with statistical procedure (Crestwell, 2003). The study was a survey in that it involved a large number of respondents. The design of the study was ex-post facto design. The population comprise 500 youths from selected communities. The sample of the study was 146 youths drawn from ten (10) communities across the state. Three (3) null hypotheses were formulated to guide the study. The research instrument used for data collection was the likert-type questionnaire titled: Youth Empowerment in Higher Education for Sustainable Development Questionnaire (YEHESDQ) The questionnaire was made up of two major sections. The first section sought the background information of youths in the communities. The second section contained 30 items on higher education and sustainable development on which youths were asked to rate their attendance and benefit in school as well as other contribution to sustainable development of their communities.

The data collected was analyzed using Pearson product moment correlation coefficient formula and a reliability coefficient of 0.81 was obtained. This high coefficient indicated that the questionnaire was reliable for use in the study. Copies of the questionnaire were administered direct to the respondents by the researcher after which the 
completed copies of the questionnaire were collected and analyzed. The result is presented below.

\section{Results}

Research hypotheses one:

Entrepreneurship programme in higher education institution for youths empowerment does not significantly influence sustainable development of the community.

Table 1. Entrepreneurship programme for youth empowerment and sustainable development of communities

\begin{tabular}{lcccccc}
\hline Variables & $\mathrm{n}$ & $\bar{X}$ & $\mathrm{SD}$ & $\mathrm{t}-\mathrm{Cal}$ & $\mathrm{t}-\mathrm{Crit}$ & $\mathrm{Df}$ \\
\hline Entrepreneurship education for youth empowerment & 76 & 78 & 10 & 3.55 & 1.98 & 144 \\
Sustainable development of community & 70 & 72 & 9.5 & & & \\
\hline
\end{tabular}

Significant at 0.05 level.

From the above table, entrepreneurship programme offered in higher educational institution to train and empower the youths had a higher mean score of 78 than the sustainability of development of communities with a mean score of 72 . The $t$-calculated (3.55) was greater than t-critical (1.9) at 0.05 level of significance and 144 degree of freedom. This result indicated that the difference between the mean scores of the two groups was statistically significant. In other words youth empowerment through entrepreneurship programme in higher education influences their contributions to sustainable development of the developing communities in the state. Therefore, the null hypothesis was rejected in favour of the alternative.

\section{Hypothesis two:}

Youth participation in higher education programme does not significantly influence their contributions to sustainable development of developing communities.

Table 2. Youth participation in higher education program and contributions to sustainable development of communities

\begin{tabular}{|c|c|c|c|c|c|c|}
\hline Variables & $\mathrm{n}$ & $\bar{X}$ & SD & $\mathrm{t}-\mathrm{Cal}$ & t-Crit & Df \\
\hline Youth participation in higher education programme contribute to & 76 & 45.7 & 5.7 & 6.36 & 1.98 & 144 \\
\hline Sustainable development of community & 70 & 38.40 & 7.9 & & & \\
\hline
\end{tabular}

Significant at 0.05 level.

From Table 2 youth participation in higher education programme had a higher mean score. The t-calculated (635) was greater than the t-critical (1.98) suggesting that there was a significant difference between the mean scores of youth participation and contribution to community development.

\section{Hypothesis three}

Youth acquisition of skills from higher education does not significantly influence sustainable development of communities.

Table 3. Youth acquisition of skills in higher education and sustainable development of developing communities

\begin{tabular}{lcccccc}
\hline Variables & $\mathrm{n}$ & $\bar{X}$ & SD & t-Cal & t-Crit & Df \\
\hline Youth acquisition of skills in higher education & 76 & 78 & 10.9 & 3.55 & 1.98 & 144 \\
Sustainable development of community & 70 & 72 & 9.5 & & &
\end{tabular}

Significant at 0.05 level.

From the results shown above, the t- calculated (1.44) was less than t-critical (1.98) indicating that there was no significant difference between the mean scores of the two groups on youth empowerment and sustainable 
development.

Generally, the results of comparing the training in higher educational institutions of youths for empowerment and their contributions to sustainable development of communities in the state as contained in Table 1 and 2 have shown that youths who have been empowered through training in higher education programmes had higher mean scores of 78 and 45.7 respectively, while their contribution5to sustainable development had mean scores of 72 and 38.40 respectively. The t-calculated value of 6.35 was greater than the critical value of 1.98 for the sub-scale. The t-calculated value of 1.44 was less than the critical value of 1.98 on the subside indicating that there was a significant difference between youths who had been employed in their contributions to sustainable development. What could be the reason for this peculiar result on Table 3 in this analysis. The researcher observed that youths who have been empowered n4ial do not contribute the same on average to sustainable development of their communities. If this holds true, then individual perception of the empowerment must have influenced the development process.

\section{Findings}

The result of the analysis of hypothesis one indicated that there is a difference between the mean scores of the two groups, it was statistically significant. In other words, youth empowerment through training in entrepreneurship programme in higher educational institutions influenced their contributions to sustainable development of developing communities.

This findings is in line with the opinion of Agagu (2008) who posit that the current level of moral decadence, crises and instability in our society may likely continue unless efforts are made to empower youths through education provides veritable tool to accomplish this empowerment. His concern is that, the provision of education for the youths will not only empower them but education would enable the youths to realize the knowledge acquired by them in their various schools that can and should be converted to self-reliance, self actualization through job creation and self development.

The National state and local Economic Empowerment State and Development Strategies (NEEDS), (SEEDS) and (LEEDS) can only be meaningful when the youths are empowered to be at the centre of it. In the second hypothesis, the result indicated that there was a significant difference between the mean scores of youths participation in higher school training and contribution to sustainable development of communities. This imply that if youths are not given the opportunity to take advantage of higher education towards empowering them for the service of the community, there is the possibility for eruption of crisis and instability in the society. This is in line with the observation of Omiyekan and Ugongi (2005) cited in Okeke and Emenalo who expressed their views that youths form the greater part of our nations' population on this note they see youths as that of creativity, vitality, enthusiasm and being bold in their aspiration. Unfortunately most of the time youths live, study and work under difficult conditions and used by unscrupulous people for dubious intentions instead of empowering them for community service.

In support of this contention, Mimiko (2009) stressed that youths need to be empowered through qualitative and functional education with unlimited life-enhancing opportunities. This would ultimately transform our youths from docile economic entity to the level of high productivity. This is an important source of making the youths to be meaningfully beneficial to themselves and the larger society. Affirming to this analytical view, National Youth Policy (2011) said that youths empowerment through education is imperative, so that, they may acquire knowledge for self-reliance, self-actualization, which will make them independent thinkers in their respective communities.

\section{Conclusion}

Youth education, specifically for empowerment purpose has become a necessity for sustainable development of developing communities. In fact, for youth to be empowered towards contributing meaningfully to sustainable development, youth issues should be held in high esteem in the society. Finally, the goal of youth development and their contribution to nation building is feasible and can only be enhanced by educational empowerment through participation and acquisition of skills.

\section{Recommendations}

- Government, stakeholders and parents should advise the youths on choice and pursuit of professional courses in higher education that will empower and give them employment bearing in mind the labour market demand principle.

- Education cost need to be reviewed to make it affordable for both parents and youth in training. 
- $\quad$ Reliable, functional and practical policies which could properly address the best way(s) and appropriately harness the creative and dynamic potential of youths for sustainable development should be evolved and sustained.

- Sustainable programme of youth awareness on the need for qualitative education towards empowerment and self-employment such as the programmes of the National orientation Agency-vocational skills development, small scale enterprises, rural employment promotion and special public works should be re-activated for the benefits of youths.

\section{References}

Abah, C. (2015). Youths are cornerstone of development. The Punch Newspaper (p. 47), May 22.

Adebayo, F. (2015). Foundation seeks entrepreneurial policies in institutions. The Punch Newspaper (p. 47), May 22.

Adebayo, F. (2015). Tinubu's wife urge, pupils to imbibe leadership spirit. The Punch Newspaper (p. 47), May 22.

Agagu, A. A. (2005). Higher Education and Future Leadership in Nigeria. In J. Babalola, A. Onuka, \& A. Onin (Eds.), Higher Education and youth preparation for work and Leadership in sub-Saharan African. Ibadan: His lineage

Crestwell, P. O. (2003). The Problem of Research in Nigerian Higher Education. Lagos: Macmillan Publishing Company.

Duke, E. (2007) Meaning and Dimensions of poverty. In M. O. Obadan (Ed.), Integrating Poverty Alleviation Strategies in Nigeria. Ibadan: NCEMA Seek Print.

Etuk, S., Etukdor-Eyo. E., \& Ekpo, T. (2009). Widening Equipment Opportunities for African youth through Higher Education. Journal of Education Research, 2(3), 345-350.

Federal Government of Nigeria. (2010). Nigerian Youth Policy. Abuja: Information Publishing Company.

Joel, M. (2015). Youths need good foundation. The Punch Newspaper (p. 47), May 22.

Mimiko, O. R. (2009). Youth, Empowerment Paper Presented at the Launching of Nigeria Structures' Union. United Kingdom November 20, 2011.

Ojedele, P. K., \& Fadokun, J. B. (2009). Problems and Issues in Higher Education in Nigeira in Educational Management. In J. B. Babalola, \& A. O. Ayeni (Eds.), Theories and Tasks. Ibadan: Macmillan Nigeria publishes Limited.

Okeke, F. N., \& Emenalo, F. C. (2008). Higher Education and Youth Empowerment for peace and security in Universities (pp. 183-196). Ibadan.

Okoro, J. (2011). Entrepreneurs' perception of entrepreneurship skills expected of business education graduates in E. A. Arubayi, N. E. Akpotu, \& E. P. Oghuvbu (Eds.), Education and training for entrepreneurship (pp. 205-211). University Printing Press, Abraka.

Okpeh, (2005). Youth Leadership and Politics. Forth Dimension Publishers.

Okpete, R. K. (2005). The Role of Society in Advancing the Education of Children and Youths. Nigerian Academic of education, 20th Annual Congress. Book of procedures (pp. 87-165). Lagos: Peacewise System. publishing House.

Stamers, L., \& Patrick, S. U. (2006). Developing Youth Moral Values in the Society Issues and Challenges. Lagos.

\section{Copyrights}

Copyright for this article is retained by the author(s), with first publication rights granted to the journal.

This is an open-access article distributed under the terms and conditions of the Creative Commons Attribution license (http://creativecommons.org/licenses/by/3.0/). 